\title{
AG and UAG induce $\beta$-casein expression via activation of ERK1/2 and AKT pathways
}

\author{
Sunan Li', Juxiong Liu', Qingkang Lv', Chuan Zhang², Shiyao Xu1', Dongxue Yang', \\ Bingxu Huang', Yalong Zeng', Yingjie Gao' and Wei Wang'
}

${ }^{1}$ College of Veterinary Medicine, Jilin University

2Department of Endocrinology and Metabolism, The Second Hospital of Jilin University, Changchun, China
Correspondence should be addressed to W Wang Email wang_wei99@jlu.edu.cn

\begin{abstract}
The ghrelin peptides were found to circulate in two major forms: acylated ghrelin (AG) and unacylated ghrelin (UAG). Previous studies showed that AG regulates $\beta$-casein (CSN2) expression in mammary epithelial cells. However, little is known about the mechanisms by which AG regulates CSN2 gene and protein expression. Evidence suggests that UAG has biological activity through GHSR1a-independent mechanisms. Here, we investigated the possible GHSR1a-mediated effect of UAG on the expression of CSN2 in primary bovine mammary epithelial cells (pbMECs) isolated from lactating cow. We found that both AG and UAG increase the expression of CSN2 in a dose-dependent manner in pbMECs in comparison with the control group. Increased expression of CSN2 was blocked by [D-Lys3]-GHRP-6 (an antagonist of the GHSR1a) and NF449 (a Gs- $\alpha$ subunit inhibitor) in pbMECs. In addition, both AG and UAG activated AKT/protein kinase B (AKT) and extracellular signal-regulated kinase 1/2 (ERK1/2) pathways, whereas [D-Lys3]-GHRP-6 and NF449 inhibited the phosphorylation of AKT and ERK1/2 in pbMECs respectively. Blockade of ERK1/2 and AKT signaling pathways prevented the expression of CSN2 induced by AG or UAG. Finally, we found that both AG and UAG cause cell proliferation through identical signaling pathways. Taken together, these results demonstrate that both AG and UAG act on ERK1/2 and AKT signaling pathways to facilitate the expression of CSN2 in a GHSR1a-dependent manner.
\end{abstract}
Key Words
- acylated ghrelin
- unacylated ghrelin
- bovine mammary epithelial cells

- $\beta$-casein
Journal of Molecular Endocrinology (2016) 56, 213-225

\section{Introduction}

Acylated (AG) and unacylated ghrelin (UAG) are circulating peptides encoded by the preproghrelin gene peptides and are mainly secreted by the X/A-like enteroendocrine cells of the stomach (Kojima et al. 1999, Muller et al. 2015). AG stimulates growth hormone (GH) release and positive energy balance by binding in the hypothalamus and pituitary gland to the only functional ghrelin receptor that has been characterized thus far, $\mathrm{GH}$ secretagogue receptor 1a (GHSR1a) (Howard et al. 1996, Barnett et al. 2010, Muller et al. 2015). The presence of an acyl side chain (mainly $n$-octanoic acid) attached to the AG peptide is required for full agonism of GHSR1a (Barnett et al. 2010, Heppner et al. 2014, Kern et al. 2014).

In addition to the gut, AG and GHSR1a were expressed in mammary glands and cultured primary mammary epithelial cells (MECs) (Zhang et al. 2013,

Published by Bioscientifica Ltd 
Jedrzejczak \& Szatkowska 2014, Ogorevc \& Dovc 2015). Therefore, understanding the regulating actions of these peptides is of interest. AG has a specific action during lactation. In addition to increasing plasma insulin, food intake, and glucose concentrations (Itoh et al. 2006, Fukumori et al. 2013), AG also affects milk production and milk components in rats and dairy cows (Nakahara et al. 2003) and affects milk fat and protein synthesis in water buffaloes (Gil et al. 2013). $\beta$-casein (CSN2) is the most abundant protein in cow milk and is often used as a marker for mammary differentiation. CSN2 was previously shown to be expressed under in vitro conditions in different species, such as in several bovine mammary cell lines (Jedrzejczak \& Szatkowska 2014), goat primary mammary cells (Zhang et al. 2013, Ogorevc $\&$ Dovc 2015), and mammary gland explants from cows. Northern blot analysis revealed that daily injection of AG significantly increased mammary gland CSN2 mRNA expression in rats (Nakahara et al. 2003). Zhang and colleagues showed that levels of CSN2 protein increased in MECs of lactating goat after treated with AG compared with control group (Zhang et al. 2013). However, the effects and mechanisms of AG in milk protein synthesis in primary bovine mammary epithelial cells (pbMECs) have not been examined.

A number of reports have been published on the regulation of $A G$ secretion in the context of energy metabolism that did not distinguish between acylmodified and des-acyl AG (ThidarMyint \& Kuwayama 2008, Delhanty et al. 2014, Pinkney 2014). In contrast to $A G$, the regulating action of UAG in the expression of CSN2 remains poorly understood. In several studies, the effects of AG are mimicked by UAG (Granata et al. 2007, Reano et al. 2014). Later studies revealed a weak but full agonism of binding by UAG to GHSR1a (Gauna et al. 2007, Heppner et al. 2014). However, the potential role of UAG in the expression of CSN2 in pbMECs has yet to be identified. Moreover, whether UAG can activate a similar pathway to $A G$ to regulate the expression of CSN2 is not clear.

G-protein-coupled receptors (GPCRs) are one of the major classes of cell surface receptors and are associated with a group of G-proteins consisting of three subunits termed alpha, beta, and gamma. G-proteins are classified into four families according to their $\alpha$ subunit:

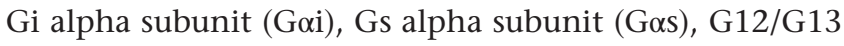
alpha subunits (Go12/13), and Gq alpha subunit $(\mathrm{G} \alpha \mathrm{q})$. Attempts to elucidate the peripheral effects of AG have identified several signaling mechanisms involving G-protein-dependent pathways, highlighting the complexity of GHSR1a activation (Evron et al. 2014, Kern et al. 2014, Yin et al. 2014). Depending on the tissues and cells, activation of GHSR1a may trigger a diverse signaling mechanism and subsequently distinct physiological responses. Both AG and UAG stimulate cell proliferation and prevent apoptosis via activation of the ERK1/2 and AKT pathways in different cells, such as pancreatic $\beta$-cells, skeletal muscle cells (Reano et al. 2014, Yu et al. 2014), and human endothelial cells (Xiang et al. 2011). In addition, both pbMEC number and activity can be affected by IGF-I signaling by activating the AKT and ERK1/2 pathways. Moreover, the AKT pathway is activated in response to milk yield (Murney et al. 2015). However, whether AG and UAG activate the ERK1/2 and AKT pathways and induce the expression of CSN2 via GHSR1a in pbMECs of lactating cows is not known.

The aim of this study was to evaluate the effects of AG and UAG on the expression of CSN2 in pbMECs of lactating cows. Furthermore, the signal pathways that are involved in the expression of CSN2 induced by both AG and UAG were also investigated.

\section{Materials and methods}

\section{Reagents}

Human AG (Ser3-Decanoyl), Human UAG (Ser3-DesOctanoyl), and [D-Lys3]-GHRP-6 were obtained from Phoenix Pharmaceuticals, Inc. (Belmont, CA, USA). Antibodies to P-ERK 1/2 (Thr202/Tyr204), ERK1/2 (Thr202/ Tyr204), AKT(Ser473), and P-AKT (Ser473) were purchased from Cell Signaling Technology Inc. Antibodies to AG, GHSR1a, and CSN2 were purchased from Abcam. Bovine insulin, prolactin, hydrocortisone, phosphatase inhibitor cocktail 2, protease inhibitor cocktail, and DAPI were obtained from Sigma. The antibodies for goat anti-rabbit IgG-HRP, rabbit anti-cytokeratin 18 (CK-18), and rabbit anti- $\beta$-tubulin (1-19) were purchased from Santa Cruz Biotechnology. The selective inhibitors of NF449 (Gos), pertussis toxin (PTX, Gai), and U0126 (ERK 1/2) were obtained from TOCRIS (Ellisville, MO, USA). The selective inhibitor of YM-254890 (Gq11) was provided by Astellas Pharma Inc. (Tokyo, Japan). The selective inhibitor of MK2206 (AKT) was from Selleckchem (Houston, DE, USA).

\section{PbMECs cultures and treatments}

PbMECs from the alveolar tissue of four mid-lactation (d 150-200 after parturition) from healthy Holstein cows were isolated using a procedure described previously

Published by Bioscientifica Ltd 
(Sorg et al. 2012, Jedrzejczak \& Szatkowska 2014). Cells were maintained in DMEM-F12, supplemented with 10\% fetal bovine serum, penicillin $(100 \mu / \mathrm{mL})$, streptomycin $(100 \mathrm{mg} / \mathrm{mL})$, bovine insulin $(5 \mu \mathrm{g} / \mathrm{mL})$, hydrocortisone $(1 \mu \mathrm{g} / \mathrm{mL})$, and prolactin $(1 \mu \mathrm{g} / \mathrm{mL})$. The expression of CK-18 was identified as a marker of pbMECs by both immunofluorescence and flow cytometry. The gene expression of CSN2, ghrelin (GHRL), and GHSR1a were detected by quantitative RT-PCR and western blot in pbMECs from passages 1-4.

The cells were treated with increasing concentrations of AG or UAG $(0,0.01,0.1,1,10$, and $100 \mathrm{ng} / \mathrm{mL})$ for 12 or $24 \mathrm{~h}$. The cells were then collected and frozen at $-80^{\circ} \mathrm{C}$ until mRNA or protein extraction. For some experiments, the cells were pre-incubated with inhibitors for $1 \mathrm{~h}$, and then treated for different time periods with AG or UAG.

A
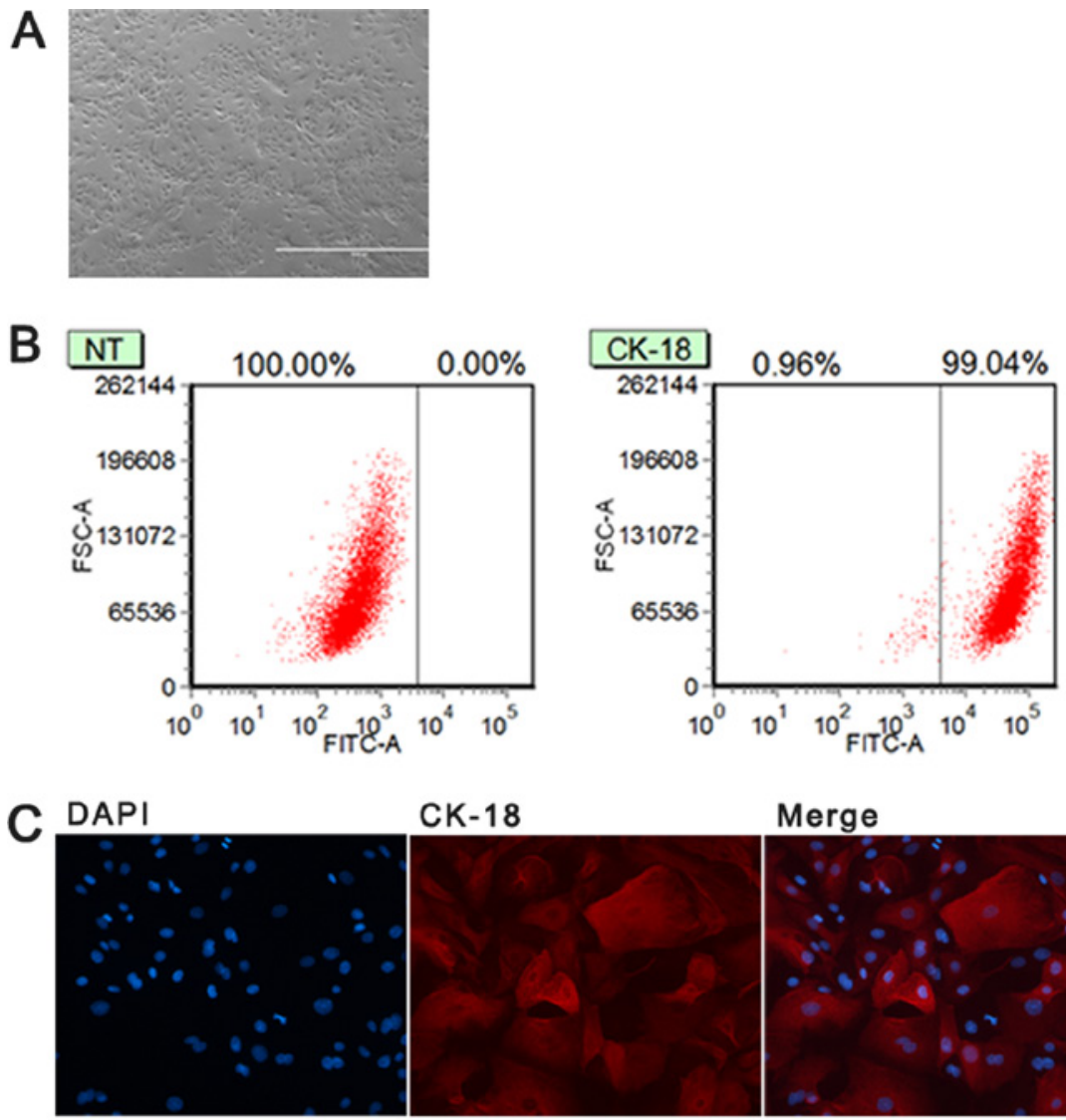

CK-18

Merge

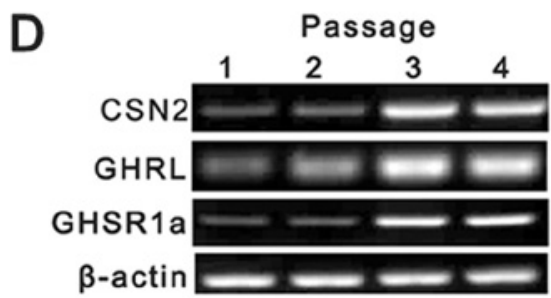

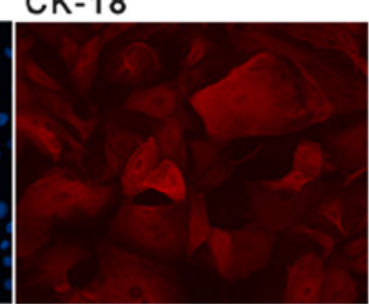
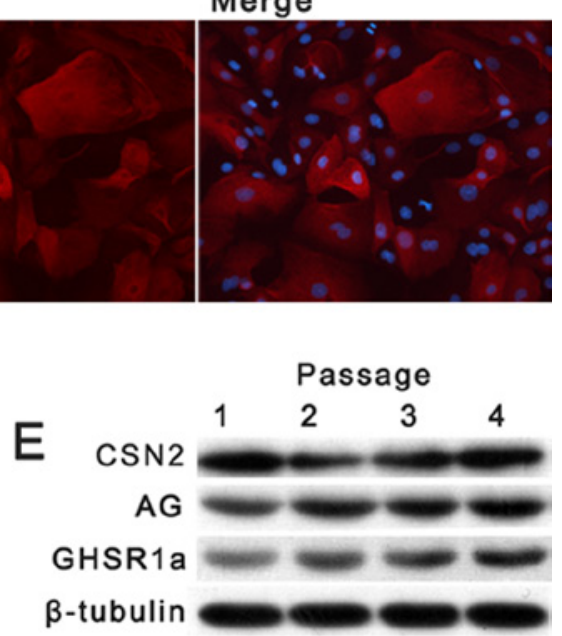

http://jme.endocrinology-journals.org DOI: 10.1530/JME-15-0287
(C) 2016 Society for Endocrinology Printed in Great Britain

\section{Quantitative RT-PCR}

After treatment with AG or UAG for different time periods, the pbMECs were harvested. Total RNA was extracted from pbMECs and reversed transcribed into cDNA from $4 \mu \mathrm{g}$ total RNA, as described previously (Li et al. 2013). The mRNA levels of various genes were evaluated using the SYBR Green QuantiTect RT-PCR Kit. The comparative 2- $2^{-\Delta c t}$ method was used to calculate the relative gene expression levels of CSN2, GHRL, and GHSR1a, with $\beta$-actin serving as the housekeeping gene. The PCR products were visualized via $1.5 \%$ agarose gel electrophoresis. The following primers were used: GHSR1a, 5'-CCGACAATGACTCGCT GACT-3' and 5'-CAAGTTCCAGGGCCGGTAAT-3'; GHRL, 5'-ATGCCCGCCCCGTGGACCAT-3' and 5'-AACCGGAT TTCCAGCTCGTC-3'; CSN2, 5'-GGCTATGGCTCCTAAGC
Figure 1

Cultured and detection of pbMECs. (A) Morphology of cultured pbMECs. Islands of epithelial cells are visible (bar $=1000 \mu \mathrm{m})$. (B) The expression of CK-18 in pbMECs was studied by flow cytometry. (C) Immunofluorescence labeling of CK-18 in pbMECs (200x magnification). (D) Gene expression of CNS2, GHSR1a, and GHRL in cultured pbMECs (passages 1-4). (E) Protein expression of CSN2, AG, and GHSR1a in pbMECs (passages 1-4). A full colour version of this figure is available at http://dx.doi.org/10.1530/ JME-15-0287. 
ACA-3' and 5'-GAGAAAGGGACAGCACGGAC-3'; and $\beta$-actin, 5'-TCACCAACTGGGACGACA-3' and 5'-GCATA CAGGGACAGCACA-3'.

\section{Western blot analysis}

After treatment with AG or UAG for different time periods, whole-cell proteins were extracted in accordance with our published protocol (Li et al. 2013). The cells were washed with ice-cold PBS and harvested using RIPA lysis buffer containing $10 \mathrm{mM}$ HEPES, pH 7.5; $10 \mathrm{mM}$ $\mathrm{KCl}$; $0.1 \mathrm{mM}$ EGTA; $0.1 \mathrm{mM}$ EDTA; phosphatase inhibitor cocktail 2, and protease inhibitor cocktail. Protein samples $(40 \mu \mathrm{g})$ were subjected to $12 \%$ SDS-PAGE and transferred to PVDF membrane (Chemicon International, Millipore, Billerica, MA, USA). After blocking with 5\% milk, the membranes were incubated overnight at $4^{\circ} \mathrm{C}$ with the specific antibodies to P-ERK1/2 (1:1000), ERK1/2 (1:2000), AKT (1:2000), P-AKT (1:1000), GHSR1a (1:4000), CSN2 (1:1000), AG (1:500), or $\beta$-tubulin $(1: 10,000)$. The membranes were washed four times with $0.1 \%$ TBS-T and incubated with goat anti-rabbit IgG-HRP for $1 \mathrm{~h}$ at room temperature (RT). The immunoreactive proteins were visualized using the ECL detection system (Millipore).

\section{Cell viability assay}

Cells were seeded in 96-well plates at a density of $5 \times 10^{4}$ cells/well and treated with AG or UAG (0, 0.01, 0.1, 1, 10, and $100 \mathrm{ng} / \mathrm{mL}$ ) for 24,48 , and $72 \mathrm{~h}$. After treatment, the cells were incubated with $1 \mathrm{mg} / \mathrm{mL}$ MTT for approximately $4 \mathrm{~h}$ and then incubated with $150 \mu \mathrm{L}$ of dimethylsulfoxide for $10 \mathrm{~min}$. The optical density of the samples was quantified by measuring the absorbance at $570 \mathrm{~nm}$ and expressed as the percentage relative to the untreated control. Each experiment included five replicates per treatment, and the experiments were repeated a minimum of three times. For some experiments, the cells were preincubated with inhibitors for $1 \mathrm{~h}$ and then treated for $24 \mathrm{~h}$ with AG or UAG.

\section{Immunofluorescence assay}

To evaluate the expression of CK-18 in pbMECs, $1 \times 10^{4}$ cells/well were seeded in a slide in 24-well plates for $24 \mathrm{~h}$. Slides were fixed with $4 \%$ paraformaldehyde in PBS for $10 \mathrm{~min}$ at RT. After blocking with 3\% normal goat serum for $2 \mathrm{~h}$ at $\mathrm{RT}$, the slides were incubated with primary antibodies to CK-18 (1:200) overnight at $4^{\circ} \mathrm{C}$. After washing, the slides were incubated with PE-conjugated goat anti-rabbit IgG (1:500) for $1 \mathrm{~h}$ at RT. DAPI was used to stain the cell nuclei at a concentration of $1.43 \mu \mathrm{M}$ for $10 \mathrm{~min}$. After staining, slides were viewed with an inverted fluorescence microscope.

\section{Flow cytometry assay}

To evaluate the population of CK-18-expressing pbMECs, the cells were seeded into 6-well plates at a density of $1 \times 10^{6}$ cells/well. After $24 \mathrm{~h}$, the cells were aspirated and

A
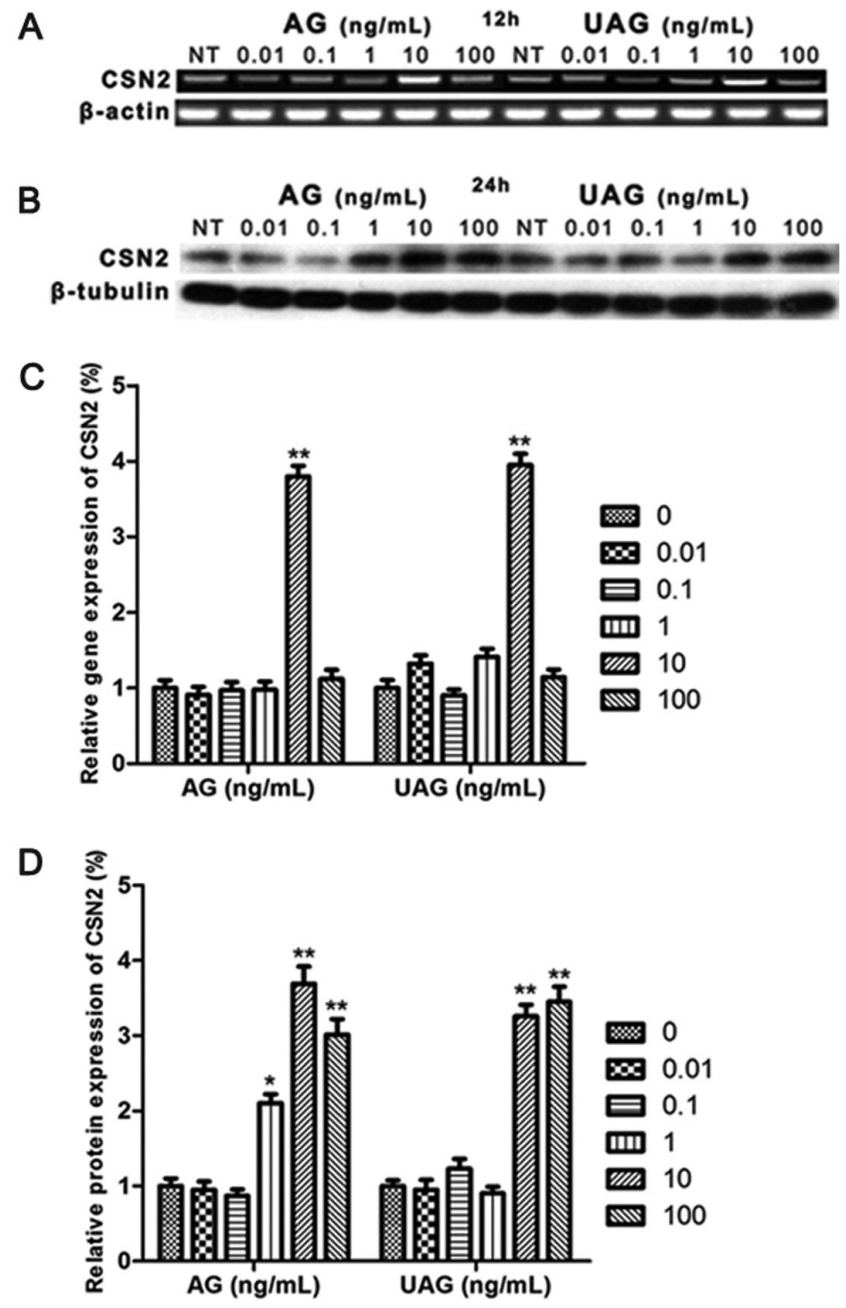

Figure 2

AG and UAG induce CSN2 gene and protein expression in pbMECs. (A) Cells were incubated for $12 \mathrm{~h}$ with increasing concentrations of AG or UAG. Gene expression of CSN2 was determined by quantitative RT-PCR. (B) Cells were incubated for $24 \mathrm{~h}$ with increasing concentrations of AG or UAG. Protein expression of CSN2 was examined by western blot. ( $C$ and D) The data are presented as the mean \pm s.D. $(n>3$ independent experiments; ${ }^{*} P<0.05, * * P<0.01$ vs non-treated (NT) control group). 
washed with PBS twice. After blocking, the cells were stained with CK-18 (1:500) for $16 \mathrm{~h}$ at $4^{\circ} \mathrm{C}$. The cells were incubated with donkey anti-rabbit IgG-FITC for $1 \mathrm{~h}$ at RT after washing. Flow cytometry (BD Biosciences, USA) was used to determine the population of $\mathrm{CK}-18^{+}$cells.

\section{Statistical analysis}

The data were analyzed using GraphPad Prism 5 (GraphPad InStat Software, San Diego, CA, USA). The comparison among groups was carried with an ANOVA followed by Dunnett's test. In each panel, experiments were repeated with similar results at least three times. Data are presented as the mean \pm s.D. A $P$-value of 0.05 or 0.01 was considered statistically significant.

\section{Results}

\section{AG and UAG promote the expression of CSN2 in pbMECs}

We first detected the morphology (Fig. 1A) and the expression of CK-18 before each experiment to ensure the purity of pbMECs. Cells from a population with 99\% CK-18 expression were used in the subsequent experiments (Fig. 1B and C). We next detected the expression of CSN2, AG, and GHSR1a in cultured pbMECs from passage 1 to passage 4 . The results showed that genes of CSN2, GHRL, and GHSR1a were expressed at passages 1-4, although the gene level was lower at passage 1 and passage 2 (Fig. 1D). Moreover, the proteins of CSN2, AG, and GHSR1a were also stably expressed in pbMECs at passages 1-4 (Fig. 1E).

Previous studies showed that AG increases CSN2 mRNA expression in MECs from dairy goats (Zhang et al. 2013). However, whether AG influences the expression of CSN2 in pbMECs is not known. In addition, UAG is a weaker agonist of GHSR1a compared with AG (Gauna et al. 2007). Therefore, we hypothesized that treatment with UAG has similar but maybe less potent effects than AG on the expression of CSN2. To test this hypothesis, the gene and protein expression of CSN2 were detected after treatment for 12 or $24 \mathrm{~h}$ with increasing concentrations of either AG or UAG in pbMECs. The results showed that compared with the non-treated (NT) control group, only $10 \mathrm{ng} / \mathrm{mL}$ AG or UAG significantly increased CSN2 gene expression (Fig. 2A, B and C). Western blot results showed that the expression of CSN2 protein was significantly higher in these pbMECs treated with AG $(1-100 \mathrm{ng} / \mathrm{mL})$
A

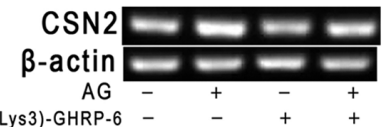

C
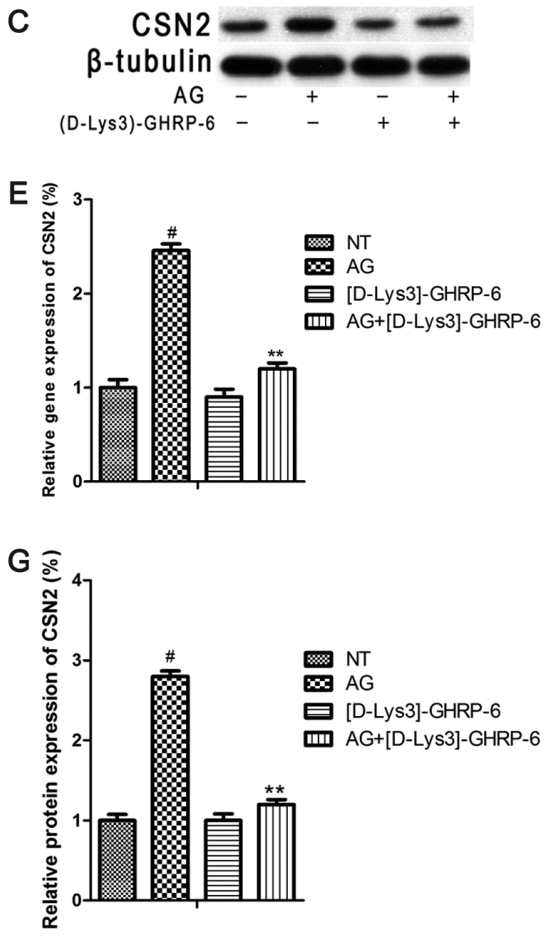

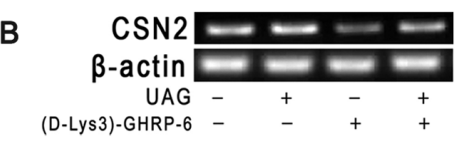

D
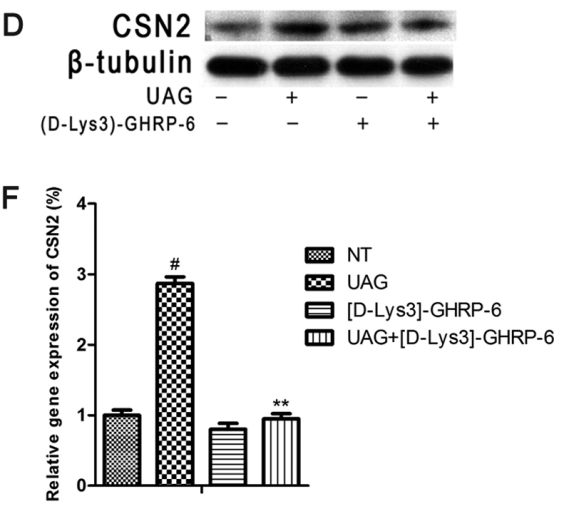

$\mathrm{H}$

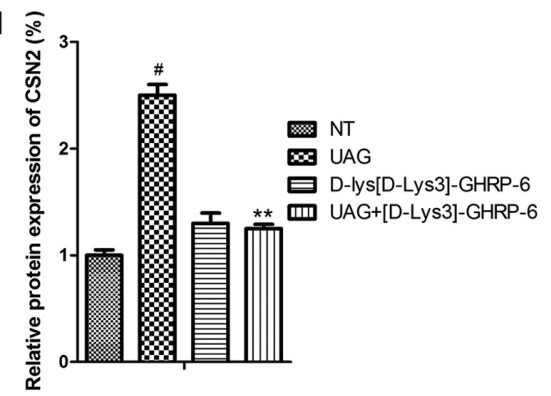

Figure 3

AG and UAG increased the expression of CSN2 in a GHSR1a-dependent manner in pbMECs. The cells were pre-treated for $1 \mathrm{~h}$ with [D-Lys3]GHRP-6 $(100 \mu \mathrm{g} / \mathrm{mL})$ and then incubated for 12 or $24 \mathrm{~h}$ with $\mathrm{AG}$ or UAG. The gene and protein expression of CSN2 was examined by (A and B) quantitative RT-PCR and ( $C$ and $D)$ western blot. $(E, F, G$, and $H$ ) The data are presented as the mean \pm S.D. $(n>3$ independent experiments; ${ }^{\#} P<0.01$ vs NT; ${ }^{*} P<0.05, * * P<0.01$ vs AG or UAG treatment). 
and peaked at $10 \mathrm{ng} / \mathrm{mL}$ and then decreased at $100 \mathrm{ng} / \mathrm{mL}$ $(P<0.01$; Fig. 2B, C and D). For UAG treatment at $10 \mathrm{ng} /$ $\mathrm{mL}$ and $100 \mathrm{ng} / \mathrm{mL}$, significantly higher values of protein expression of CSN2 were observed $(P<0.01$; Fig. $2 \mathrm{~B}, \mathrm{C}$ and $D)$. In addition, we also investigated whether AG and UAG influences the expression of GHSR1a in pbMECs. Our results showed that both $A G$ and UAG have no significant effect on GHSR1a gene and protein expression (Supplementary Figure 1, see section on supplementary data given at the end of this article). Considering the above results, $10 \mathrm{ng} / \mathrm{mL}$ was selected as the best concentration for $A G$ and $U A G$ in subsequent experiments.

\section{GHSR1a and Gos are required for AG- and UAG-induced expression of CSN2 in pbMECs}

Previous research reported that both AG and UAG regulate peripheral glucose metabolism through a GHSR1a-dependent mechanism (Heppner et al. 2014).
[D-Lys3]-GHRP-6 is regarded as a highly selective GHSR1a antagonist and has been widely used to investigate the dependency of GHSR1a signaling (Granata et al. 2007, Zhang et al. 2013). To determine whether the effect of AG and UAG on the expression of CSN2 depends on GHSR1a activation, pbMECs were pre-incubated with [D-Lys3]-GHRP-6 $(100 \mu \mathrm{g} / \mathrm{mL})$ for $1 \mathrm{~h}$, followed with AG or UAG for $24 \mathrm{~h}$. The results showed that both AG and UAG significantly increased gene and protein expression of CSN2 in pbMECs compared with the NT control group (Fig. 3A, B, C, D, E, F, G, and H). However, the increased gene level of CSN2 was inhibited by [D-Lys3]-GHRP-6 $(P<0.01$; Fig. 3A, B, E, and F). Moreover, increased protein level of CSN2 was also suppressed by [D-Lys3]-GHRP-6 $(P<0.01$; Fig. 3C, D, G, and H). However, stimulation with [D-Lys3]-GHRP-6 alone had no significant effects on the expression of CSN2 compared with the NT control group.

AG binding to GHSR1a has been shown to activate

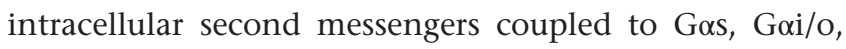

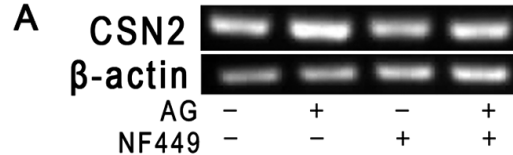

C

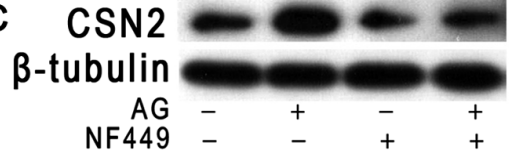

E

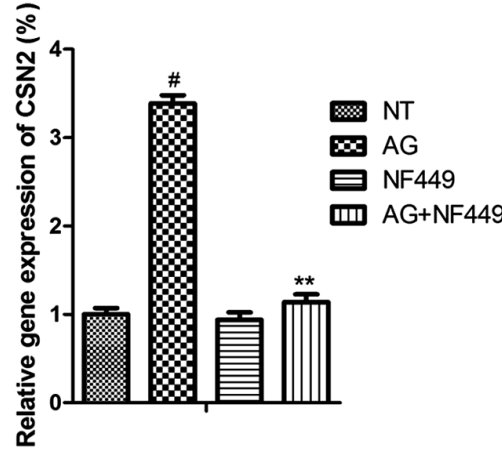

G

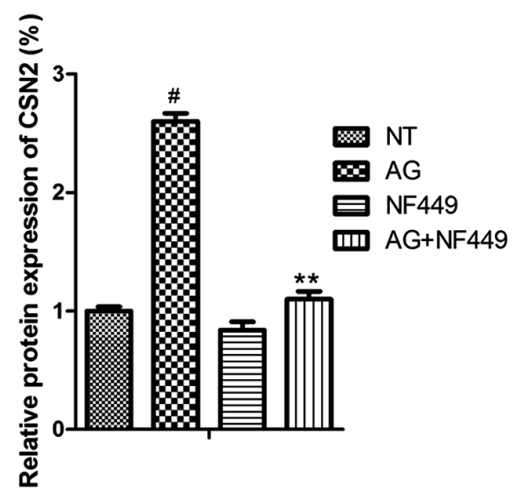

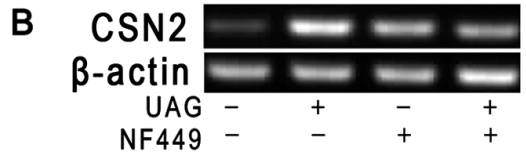

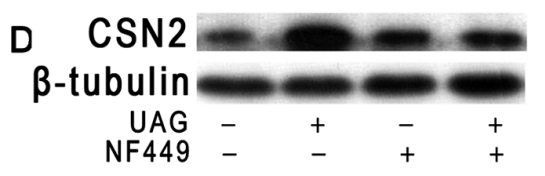

F
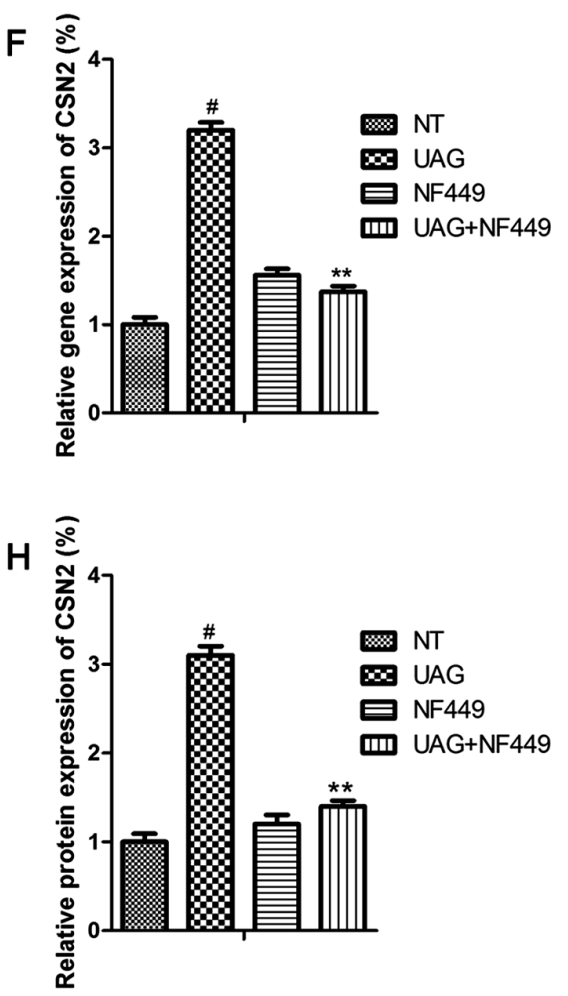

Figure 4

Gos is coupled to GHSR and is required for AG- and UAG-induced expression of CSN2 in pbMECs. The cells were pre-treated for $1 \mathrm{~h}$ with NF449 $(10 \mu \mathrm{M})$ and then incubated for 12 or $24 \mathrm{~h}$ with AG or UAG. The gene and protein expression of CSN2 was examined by (A and B) quantitative RT-PCR and ( $C$ and $D$ ) western blot. $(E, F, G$, and $H)$ The data are presented as the mean \pm S.D. ( $n>3$ independent experiments; $\# P<0.01$ vs NT; $* P<0.05, * * P<0.01$ vs AG or UAG treatment). http://jme.endocrinology-journals.org DOI: 10.1530/JME-15-0287
๑) 2016 Society for Endocrinology Printed in Great Britain 
A

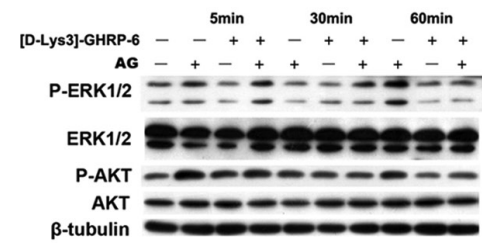

C

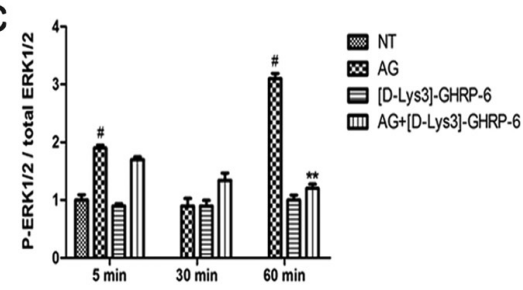

E

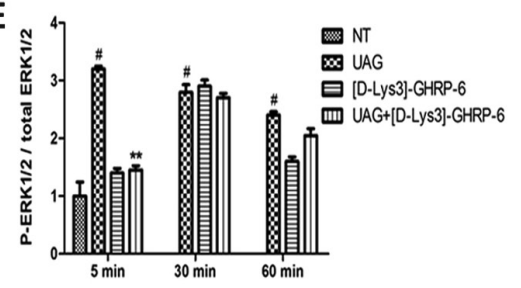

B

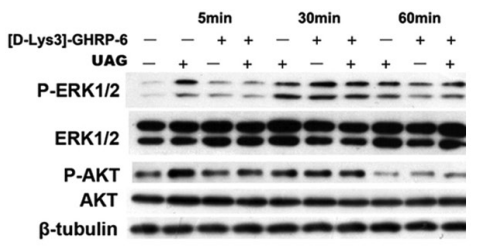

D

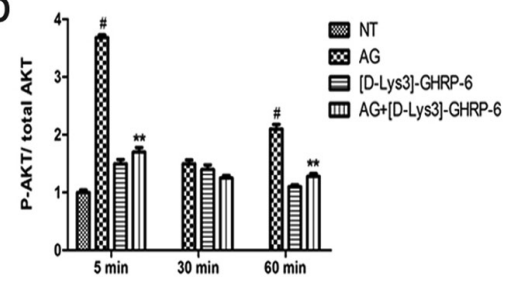

F

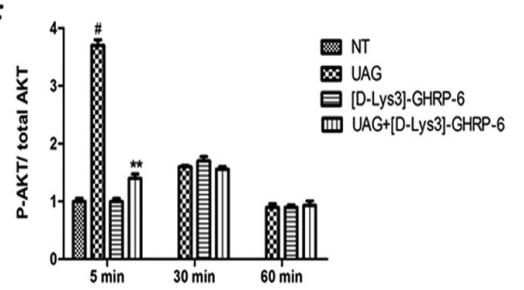

Figure 5

AG and UAG induce ERK $1 / 2$ and AKT phosphorylation in GHSR-dependent manner in pbMECs. Cultured pbMECs were incubated with either AG or UAG in the presence or absence of [D-Lys3]-GHRP-6 $(100 \mu \mathrm{g} / \mathrm{mL})$ for 5,30 , and 60 min. At the indicated time points, cell lysates were prepared and subjected to western blotting using ERK1/2, P-ERK1/2, AKT, and P-AKT antibodies. (A and B) AG- and UAG-induced phosphorylation of ERK $1 / 2$ and AKT were abolished upon treatment with [D-Lys3]-GHRP-6. $(C, D, E$, and F) Bar graph showing mean of P-ERK $1 / 2$ and P-AKT levels. ( $n>3$ independent experiments; ${ }^{P} P<0.01$ vs NT; $* P<0.05, * * P<0.01$ vs AG or UAG treatment). and G $\alpha \mathrm{q} / 11$ and enhanced GH release, appetite, and proliferation (Granata et al. 2007, Evron et al. 2014, Reano et al. 2014). GHSR1a couples to different intracellular signaling pathways and mediates different effects depending on the cell type. However, which G-protein subunits couple to GHSR1a to mediate the effect of AG or UAG in pbMECs remains unknown. To investigate this mechanism, the cells were pre-incubated for $1 \mathrm{~h}$ with NF449 $(10 \mu \mathrm{M})$, YM254890 $(10 \mu \mathrm{M})$, and PTX $(10 \mu \mathrm{M})$, which are selective $\mathrm{G} \alpha \mathrm{s}, \mathrm{Gq} / 11$, and Gi/o protein-coupled receptor antagonists respectively. Next, the cells were incubated for 12 or $24 \mathrm{~h}$ with AG or UAG. Pre-incubation with NF449 resulted in a complete blockade of both AG- and UAG-induced gene and protein expression of
A

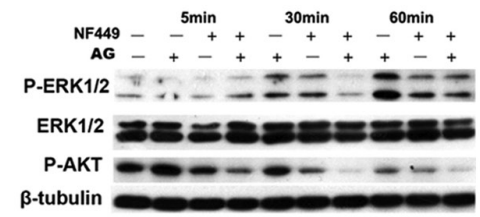

C

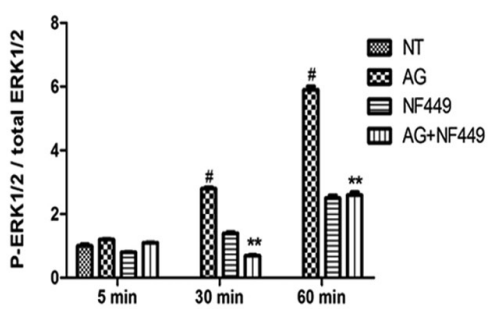

E

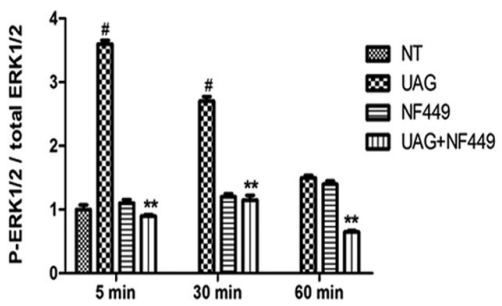

B

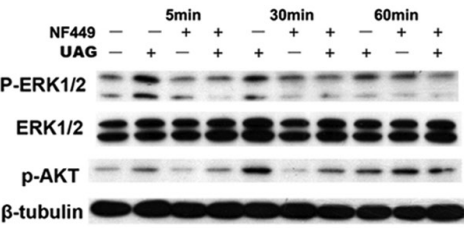

D

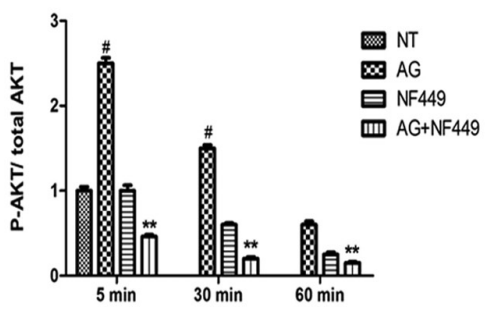

F

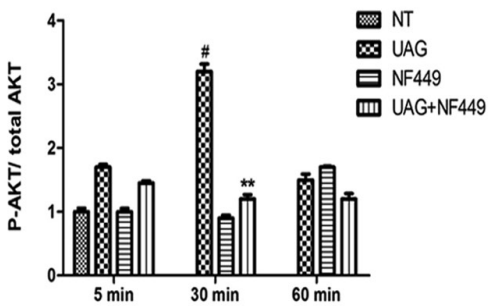

Figure 6

Gos is required for ERK $1 / 2$ and AKT

phosphorylation induced by AG or UAG in pbMECs. Cells were incubated with either AG or UAG in the presence or absence of NF449 $(10 \mu \mathrm{M})$ for 5,30 , and $60 \mathrm{~min}$. At the indicated time points, cell lysates were prepared and subjected to western blotting using ERK1/2, P-ERK1/2, AKT, and P-AKT antibodies. (A and B) Phosphorylation of ERK $1 / 2$ and AKT activated by AG or UAG was inhibited by NF449, a Gas subunit-selective G-protein antagonist. (C, D, E, and F) Bar graph showing mean of P-ERK $1 / 2$ and P-AKT levels. ( $n>3$ independent experiments; $\# P<0.01$ vs NT; ${ }^{*} P<0.05, * * P<0.01$ vs AG or UAG treatment). http://jme.endocrinology-journals.org DOI: 10.1530/JME-15-0287
๑) 2016 Society for Endocrinology Printed in Great Britain 
CSN2 ( $P<0.01$; Fig. 4A, B, C, D, E, F, G, and H). However, treatment with PTX and YM-254890 had no effect on both AG- and UAG-induced mRNA and protein expression of CSN2 in pbMECs (Supplementary Figure 2). These results implied that activation of GHSR1a by AG and UAG is likely coupled to Gas, not Gq/11 and Gi/o, and promotes the expression of CSN2 in pbMECs.

\section{AG and UAG induce ERK1/2 and AKT phosphorylation in pbMECs via activation of GHSR1a and Gos}

Recent studies have demonstrated that under defined conditions, GHSR1a couples to Gos, resulting in activation of phospho-ERK1/2 and phospho-AKT (Granata et al. 2007, Evron et al. 2014, Kern et al. 2014). Thus, we next assessed the potential role of GHSR1a in regulating the activation of ERK1/2 and AKT signaling in pbMECs. The cells were pre-incubated with [D-Lys3]-GHRP-6 for $1 \mathrm{~h}$ and followed with AG or UAG for 5, 30, and $60 \mathrm{~min}$. After treatment with AG, the phosphorylation of ERK1/2 and AKT was significantly increased compared with the NT control group but suppressed after pre-incubation with [D-Lys3]-GHRP-6 at $60 \mathrm{~min}$ for phospho-ERK1/2, or 5 and $60 \mathrm{~min}$ for phospho-AKT, respectively $(P<0.01$; Fig. $5 \mathrm{~A}$, $C$, and $\mathrm{D})$. In addition, the increased phosphorylation of ERK1/2 and AKT induced by UAG was also blocked by [D-Lys3]-GHRP-6 at 5 min for phospho-ERK1/2 and phospho-AKT compared to with the NT control group, respectively $(P<0.01$; Fig. 5B, E, and F).

Our previous results showed that AG- and UAGinduced expression of CSN2 involves a Gos protein-coupled receptor, which, in turn, has been shown to activate ERK1/2 and AKT signaling (Granata et al. 2007, Yu et al. 2014). Therefore, we investigated whether these pathways mediate the increased expression of CSN2 induced by AG or UAG. In agreement, NF449 also inhibited AG-induced ERK1/2 phosphorylation at 30 and $60 \mathrm{~min}(P<0.01$; Fig. 6A and $\mathrm{C}$ ), and increased phospho-AKT was also suppressed by NF449 at 5, 30, and 60 min $(P<0.01$; Fig. 6 A and D). In addition, stimulation of pbMECs with UAG leads to significantly increased phosphorylation of ERK1/2, which is reduced by NF449 at 5, 30, and $60 \mathrm{~min}(P<0.01$;
A

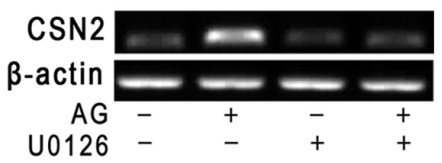

C

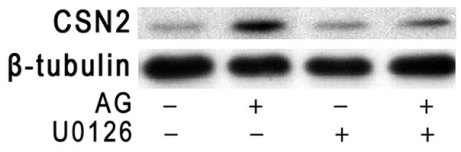

$\mathrm{E}$

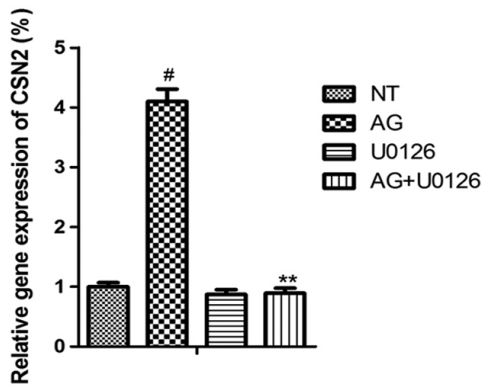

G

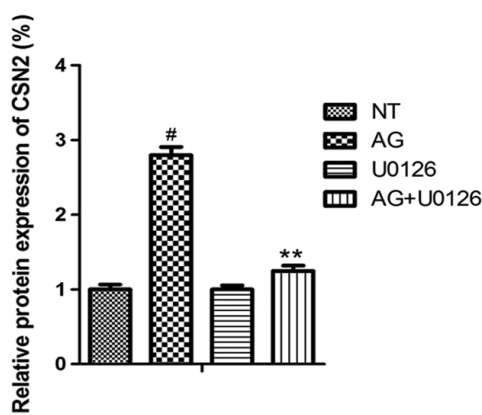

B

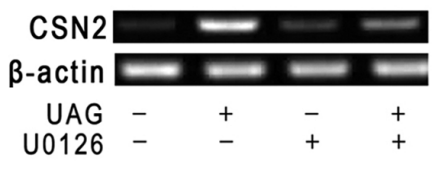

D

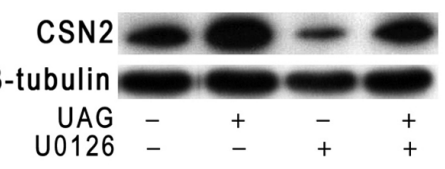

$\mathrm{F}$

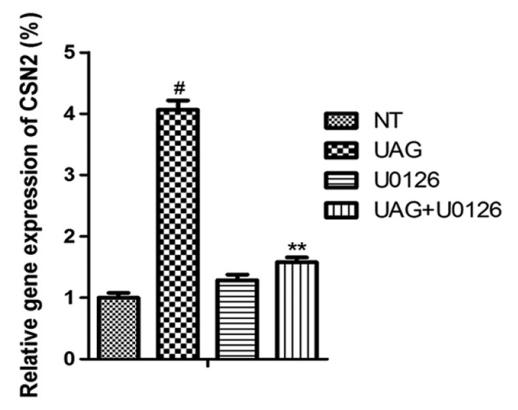

$\mathrm{H}$

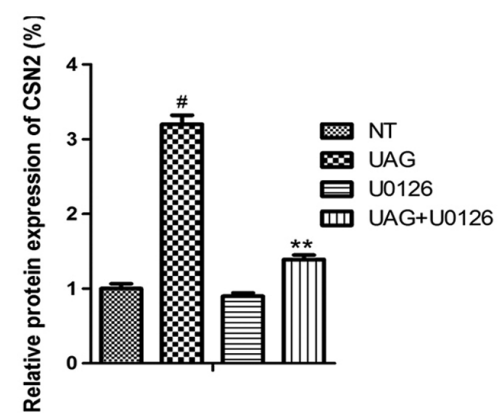

Figure 7

AG and UAG induce the expression of CSN2 through the ERK1/2 signaling pathway in pbMECs. The cells were pre-treated for $1 \mathrm{~h}$ with U0126 $(10 \mu \mathrm{M})$, followed by AG or UAG for 12 or $24 \mathrm{~h}$. The gene and protein expression of CSN2 was examined by (A and $B$ ) quantitative RT-PCR and ( $C$ and D) western blot. ( $E, F, G$ and $H)$ The data are presented as the mean \pm S.D. ( $n>3$ independent experiments; $P<0.01$ vs NT; ${ }^{\star} P<0.05,{ }^{*} P<0.01$ vs AG or UAG treatment). http://jme.endocrinology-journals.org DOI: 10.1530/JME-15-0287
C) 2016 Society for Endocrinology Printed in Great Britain 
Fig. 6B and E). Moreover, induced phospho-AKT was also decreased at $30 \mathrm{~min}(P<0.01$; Fig. $6 \mathrm{~B}$ and $\mathrm{F})$; however, no effect was found using inhibitors alone. These results suggested that GHSR1a and Gos are required for AG- and UAG-induced phosphorylation of ERK1/2 and AKT in pbMECs.

\section{AG and UAG stimulate the expression of CSN2 by activating ERK1/2 and AKT signaling}

To further determine the potential role of ERK1/2 and AKT pathways in AG- and UAG-induced expression of CSN2 in pbMECs, the cells were pre-incubated for $1 \mathrm{~h}$ with U0126 and MK2206, which are specific inhibitors of ERK1/2 and AKT respectively. Our results showed that treatment with U0126 resulted in a significant blockade of ERK1/2 phosphorylation (data not shown). The gene and protein levels of CSN2 induced by AG and UAG were also inhibited by U0126 in pbMECs $(P<0.01$; Fig. 7$)$. In addition, stimulated with MK2206 for $1 \mathrm{~h}$ completely blockaded the phosphorylation of AKT in pbMECs (data not shown). Increased gene and protein expression of CSN2 was also suppressed by MK2206 in pbMECs $(P<0.01$; Fig. 8). However, stimulation with U0126 and MK2206 alone had no significant effects on the expression of CSN2 compared with the NT control group. Together, these results demonstrated that AG- and UAG-induced expression of CSN2 might depend on the phosphorylation of ERK1/2 and AKT in pbMECs.

\section{AG and UAG stimulate cell proliferation in pbMECs}

Both AG and UAG not only stimulated cell proliferation but also suppressed apoptosis in pancreatic $\beta$-cells, skeletal muscle, and macrophages (Gauna et al. 2007, Evron et al. 2014, Li et al. 2015). Thus, finally, we investigated the effects of increasing the concentration of AG and UAG treatment on the growth of pbMECs. As shown in Fig. 9, compared with the NT control group, pbMECs proliferation was enhanced following increased AG stimulation for 24,48 , and $72 \mathrm{~h}$, with the maximum
A

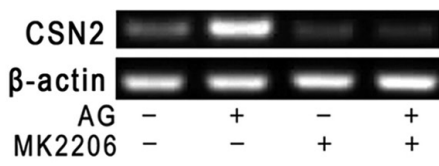

C

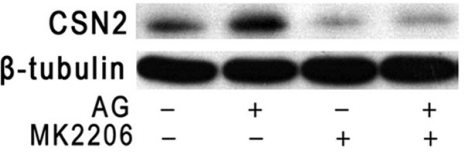

E

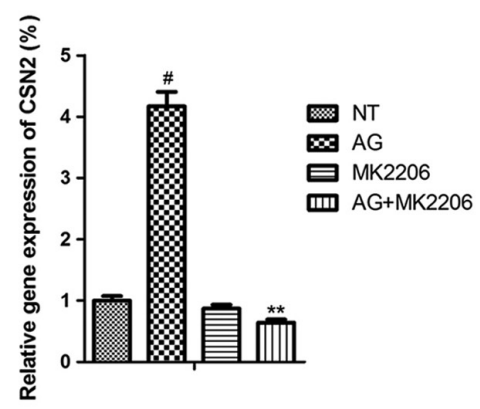

G

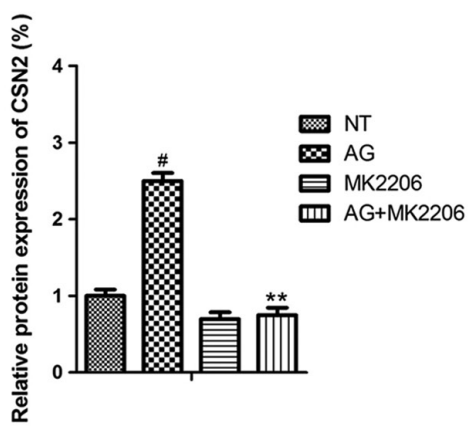

B

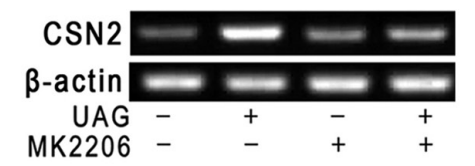

D

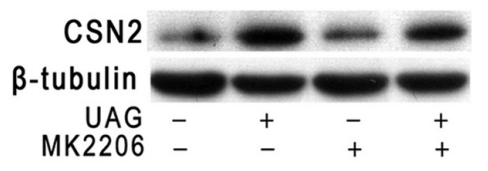

F

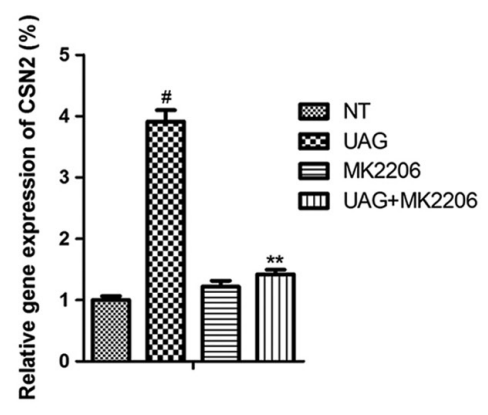

$\mathrm{H}$

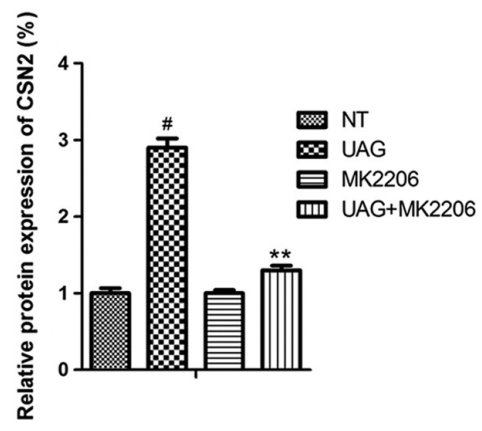

Figure 8

AG and UAG induce the expression of CSN2 through the AKT signaling pathway in pbMECs. The cells were pre-treated for $1 \mathrm{~h}$ with MK2206 $(10 \mu \mathrm{M})$, followed by AG or UAG for 12 or $24 \mathrm{~h}$. The gene and protein expression of CSN2 were examined by ( $E$ and $F$ ) quantitative RT-PCR and ( $A$ and $B$ ) western blot ( $C$ and $D) .(E, F, G$, and $H$ ) The data are presented as the mean \pm S.D. $(n>3$ independent experiments; $\# P<0.01$ vs NT; ${ }^{*} P<0.05,{ }^{*} P<0.01$ vs AG or UAG treatment). http://jme.endocrinology-journals.org DOI: 10.1530/JME-15-0287
○ 2016 Society for Endocrinology Printed in Great Britain 
A

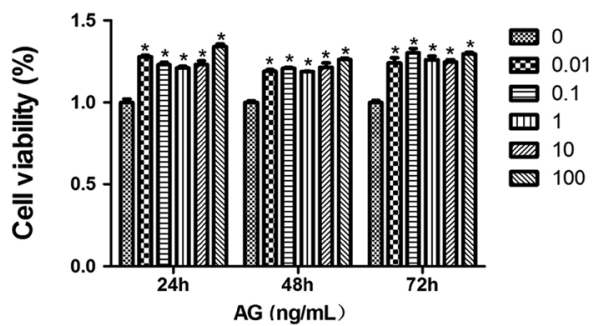

B

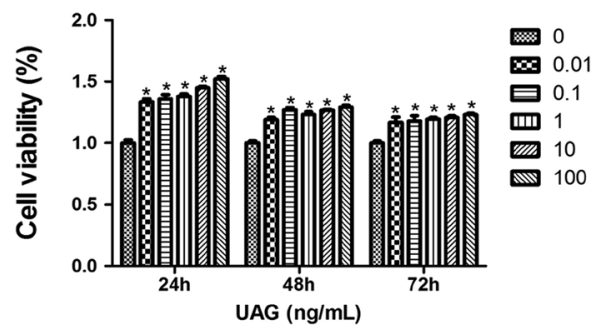

C

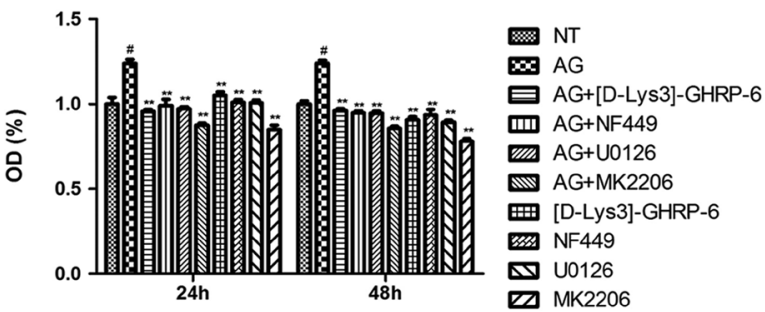

D

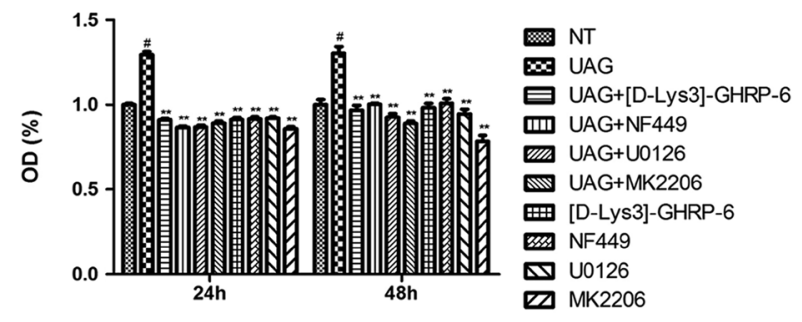

Figure 9

$A G$ and UAG induce pbMEC proliferation. PbMECs were cultured with increasing concentrations of AG or UAG for 24,48 , and $72 \mathrm{~h}$ with or without AG or UAG. Then, cell proliferation was measured in a MTT assay. (A and B) AG and UAG markedly enhanced cell proliferation at 24,48 , or $72 \mathrm{~h}$. The cells were pre-treated for $1 \mathrm{~h}$ with D-Lys, NF449, U0126, or MK2206, followed by AG or UAG for 24 and $48 \mathrm{~h}$. (C and D) AG- and UAG-induced cell proliferation were inhibited by D-Lys, NF449, U0126, or MK2206. Values are presented as the mean \pm S.D. $(n>3$ independent experiments; $\# P<0.01$ vs NT; ${ }^{*} P<0.05, * * P<0.01$ vs AG or UAG treatment).

proliferative response at $100 \mathrm{ng} / \mathrm{mL}(P<0.05$; Fig. 9A). In addition, UAG significantly induced cell proliferation in a dose-dependent manner at $24 \mathrm{~h}$, and was lower but still above basal level after 48 and $72 \mathrm{~h}(P<0.05$; Fig. 9B). These results suggested that cell proliferation was markedly enhanced as the concentration of AG and UAG. However, there were no cytotoxic effects on the growth of pbMECs.

To examine whether GHSR1a and Gas mediate AGand UAG-induced proliferation in pbMECs, the cells were pre-incubated with [D-Lys3]-GHRP-6 and NF449 for $1 \mathrm{~h}$ followed by incubation with AG or UAG. The results showed that pre-incubation with [D-Lys3]-GHRP-6 or NF449 remarkably reduced AG- or UAG-induced proliferation in pbMECs compared with AG or UAG group $(P<0.05$; Fig. 9C and D). To elucidate whether activation of the ERK1/2 and AKT pathways are required to AG- and UAG-induced proliferation, we assessed the effect of U0126 and MK2206. Both AG- and UAG-induced cell proliferations were blocked by U0126 or MK2206 in pbMECs compared with AG group $(P<0.05$; Fig. 9C and D). In addition, stimulation with [D-Lys3]-GHRP-6, NF449, U0126, and MK2206 alone had no significant effect on cell proliferation compared with the NT control group. These results showed that cell proliferation induced by AG or UAG was likely mediated through a GHSR1a and Gas signal cascade.

\section{Discussion}

Our findings show that both AG and UAG increase the gene and protein expression of CSN2 in pbMECs of lactating cows. The ERK1/2 and AKT signal pathway that is activated by GHSR1a and Gos likely mediates these effects.

The initiation of lactation dramatically alters the metabolism of many organs so that the mammary glands can be supplied with the nutrients necessary for milk protein synthesis (Yu et al. 2015). Protein production is controlled by the complex interplay of peptide and steroid hormones, predominantly the lactogenic hormones: prolactin, insulin, and hydrocortisone. More recently, other hormones have been discovered in breast milk such as AG (Savino et al. 2012). The third amino acid residue of AG, serine (Ser3), is modified by an acyl group; this modification is essential for AG biological activity. In addition to $n$-octanoyl AG, other forms of AG peptide exist, including UAG, which lacks an acyl modification, and other acylated AG species, such as $n$-decanoyl AG, whose Ser 3 residue is modified by $n$-decanoic acid (Yoh et al. 2011). It has been shown that $n$-decanoyl AG was one of the active forms of the AG peptide and that it could interact with the receptor in a manner similar to that of $n$-octanoyl AG. A number of reports on the regulation of AG secretion in the context of energy metabolism and food intake in cows that did not distinguish between acyl-modified and des-acyl AG have been published (Itoh et al. 2006, ThidarMyint et al. 2006, Bradford \& Allen 2008, Roche et al. 2008, ThidarMyint \& Kuwayama 2008, Fukumori et al. 2013). In addition, the effects of $n$-octanoyl 
AG on plasma concentrations of glucose and milk yield and quality in lactation cows have been described in detail (Itoh et al. 2006, Roche et al. 2008, Gil et al. 2013). However, the effects and mechanisms of $n$-octanoyl AG and UAG in milk protein synthesis in vitro have not been examined. Thus, $n$-octanoyl AG and UAG were used in our experiment.

We first evaluated the effects of AG on the expression of CSN2 in pbMECs of lactation cows. With the exception of the epithelial cells of alveoli and ducts throughout the lactation in dairy goats (Zhang et al. 2013), our results demonstrated that AG and GHSR1a were expressed in pbMECs. We also find that only $10 \mathrm{ng} / \mathrm{mL}$ AG significantly increased the gene expression of CSN2. Western blot results showed that the expression of CSN2 protein was significantly higher in these pbMECs treated with a concentration range of $1-100 \mathrm{ng} / \mathrm{mL}$ compared with NT control group. Previous studies suggested that unlike AG, UAG is not acylated at Ser3 (Delhanty et al. 2013, 2014), and its effect on the expression of CSN2 has not been elucidated. However, here we show for the first time that $U A G$, similar to AG, significantly stimulated the gene expression of CSN2. Although the expression of CSN2 mRNA after treatment with UAG exhibited a similar tendency with AG-treated group, there are some different effects between AG and UAG. We observed significantly increased protein expression of CSN2 when treated with $1 \mathrm{ng} / \mathrm{mL}$ of AG compared with NT control group; however, there is no significantly increased when treated with UAG. Furthermore, highest protein expression of CSN2 was achieved in $10 \mathrm{ng} / \mathrm{mL}$ of $\mathrm{AG}$, whereas $100 \mathrm{ng} / \mathrm{mL}$ for UAG. The cause of this results maybe that UAG is a full agonist of the GHSR1a, with activity in the high nanomolar range (Gauna et al. 2007). In a word, our results suggested that AG and UAG could directly modulate the expression of CSN2 in the cultured pbMECs, this is in agreement with findings in goat (Zhang et al. 2013).

The specific receptor mediating the signaling responses to AG or UAG in pbMECs is unknown. Cell-based assays have demonstrated that AG requires acylation at the Ser3 residue to activate GHSR1a at concentrations within the low-nanomolar range (Heppner et al. 2014). This evidence led to the assumption that the biological effects of UAG are independent of GHSR1a activation. However, a more recent study reported that UAG interacts with GHSR1a at concentrations within the high-nanomolar or micromolar range. Although some data indicate that UAG is a weak GHSR1a agonist, other data suggest that UAG is actually a full agonist of GHSR1a and induces similar maximal receptor stimulation as $A G$, such as the regulation of cell proliferation and glucose metabolism (Chung et al. 2013, Pinkney 2014). Thus, we investigated whether the effects of AG or UAG on the expression of CSN2 were dependent on GHSR1a. Our results showed that both AG- and UAGinduced expression of CSN2 were significantly blocked by [D-Lys3]-GHRP-6, an inhibitor of GHSR1a. Altogether, our in vitro results are consistent with the literature and suggest that UAG is an agonist of GHSR1a and regulates the expression of CSN2 in pbMECs.

GHSR1a belongs to the class A G-protein-coupled receptor (GPCR) family. When GHSR1a binds to the GPCR, a conformational change occurs in the GPCR, which allows it to activate an associated G-protein such

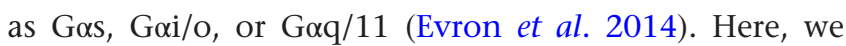
have investigated which G-protein subunit couples to GHSR1a in AG- and UAG-induced expression of CSN2 in pbMECs. We find that only NF449, the specific inhibitor of Gas, significantly reduced both AG and UAG-induced expression of CSN2 at both the gene and protein levels in pbMECs, whereas PTX and YM-254890 had no effect (data not shown). This result revealed the selective coupling of activated GHSR1a to G-protein subtypes.

Previous studies demonstrated that AG is correlated with the expression of CSN2 in vivo or in vitro in different species (Gil et al. 2013, Nakahara et al. 2003, Zhang et al. 2013). However, the mechanisms of this correlation are undefined. Downstream signaling of GHSR1a is mediated by several signaling pathways including the receptors ERK1/2 and AKT (Gauna et al. 2007, Xiang et al. 2011, Evron et al. 2014, Reano et al. 2014). It is well known that ERK1/2 and AKT play important roles in the regulation of cell survival (Xiang et al. 2011). AG- or UAG-induced activation of ERK1/2 and AKT is observed in many cell types, such as pancreatic $\beta$-cell line HIT-T15 (Evron et al. 2014), pancreatic $\beta$-cells, and macrophages (Li et al. 2015). To uncover the molecular mechanism underlying the tissue-specific response in GHSR1a-mediated intracellular signaling, we investigated the phosphorylation of ERK1/2 and AKT. In agreement with previous findings, stimulation by AG or UAG induces significant activation of ERK1/2 and AKT compared with NT control group (Granata et al. 2007). However, increased phosphorylation of ERK1/2 or AKT induced by AG or UAG was suppressed after pre-incubated with the inhibitor of GHSR1a, [D-Lys3]GHRP-6. Moreover, previous research demonstrated that G-protein signaling cascades play an important role in prolactin-induced synthesis of milk products (Howard et al. 1996, Larrea et al. 1999). AG binding to GHSR1a has http://jme.endocrinology-journals.org DOI: 10.1530/JME-15-0287
() 2016 Society for Endocrinology Printed in Great Britain
Published by Bioscientifica Ltd 
been shown to activate intracellular second messengers

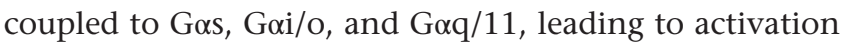
of AKT, ERK1/2, AMPK, or mTOR signal pathways (Xiang et al. 2011). GHSR1a couples to different intracellular signaling pathways depending on the cell type. Here, our results showed that only treatment with NF449 for $1 \mathrm{~h}$ inhibited the phosphorylation of ERK1/2 and AKT induced by AG or UAG in pbMECs. This observation is consistent with the report of Granata that Gos is required for AG- or UAG-induced phosphorylation of ERK1/2 and AKT (Granata et al. 2007).

To further determine whether the ERK1/2 and AKT pathway are required for the expression of CSN2 induced by AG or UAG, we examined the effect of U0126 and MK2206, which are specific inhibitors of ERK1/2 and AKT respectively. The chemical inhibition of ERK1/2 and AKT resulted in a significant suppression of AG- and UAG-induced expression of CSN2 in pbMECs, indicating that both $A G$ and UAG stimulated the expression of CSN2 via activation of the ERK1/2 and AKT signaling pathways. Although previous studies indicate that mTOR and STAT5 signaling pathways play an important role in milk protein synthesis in the lactating cows (Kojima et al. 1999), here we are the first to demonstrate that activation of GHSR1a by AG or UAG may couple to Gas and signals to ERK1/2 and AKT to increase CSN2 expression in pbMECs.

It has shown that both AG and UAG promote cell proliferation and inhibit apoptosis in pancreatic $\beta$-cells (Granata et al. 2007), endothelial cells, and skeletal muscle cell (Yu et al. 2014). Milk proteins are synthesized and excreted by MECs during lactation. We presume that the milk protein synthesis within the MECs may be regulated through cell proliferation. In agreement, our results also proved that both AG and UAG stimulate pbMECs proliferation in a dose-dependent manner at $24 \mathrm{~h}$, even for $48 \mathrm{~h}$. Pre-treatment with [D-Lys3]GHRP-6 and NF449 abolishes AG- or UAG-induced cell proliferation in pbMECs. In addition, the ERK1/2 and AKT inhibitors U0126 and MK2206, respectively, also suppress cell proliferation induced by AG or UAG. These results are consistent with previous reports that activation of the ERK1/2 and AKT pathways regulate pbMEC number and activity (Murney et al. 2015).

Collectively, our results demonstrate that GHSR1a is a Gas-coupled receptor involved in the AG- and UAGinduced expression of CSN2 in pbMECs and that increased the expression of CSN2 induced by either AG or UAG are likely mediated by the phosphorylation of ERK1/2 and AKT signaling pathways.
Supplementary data

This is linked to the online version of the paper at http://dx.doi.org/10.1530/ JME-15-0287

\section{Declaration of interest}

The authors declare that there is no conflict of interest that could be perceived as prejudicing the impartiality of the research reported.

\section{Funding}

This work was funded by the National Natural Science Foundation of China (project number 31372396 and 31572479), the Jilin Scientific and Technological Development Program (project no. 20130206036NY), and the Graduation Innovation Fund of Jilin University (project number 2015006), "985 Project" of Jilin University, Graduate Innovation Fund of Jilin University (project no. 2015861220).

\section{References}

Barnett BP, Hwang Y, Taylor MS, Kirchner H, Pfluger PT, Bernard V, Lin YY, Bowers EM, Mukherjee C, Song WJ, et al. 2010 Glucose and weight control in mice with a designed ghrelin O-acyltransferase inhibitor. Science 330 1689-1692. (doi:10.1126/science.1196154)

Bradford BJ \& Allen MS 2008 Negative energy balance increases periprandial ghrelin and growth hormone concentrations in lactating dairy cows. Domestic Animal Endocrinology 34 196-203. (doi:10.1016/j.domaniend.2007.02.002)

Chung H, Li E, Kim Y, Kim S \& Park S 2013 Multiple signaling pathways mediate ghrelin-induced proliferation of hippocampal neural stem cells. Journal of Endocrinology 218 49-59. (doi:10.1530/JOE-13-0045)

Delhanty PJ, Neggers SJ \& van der Lely AJ 2013 Des-acyl ghrelin: a metabolically active peptide. Endocrine Development 25 112-121. (doi:10.1159/000346059)

Delhanty PJ, Neggers SJ \& van der Lely AJ 2014 Should we consider desacyl ghrelin as a separate hormone and if so, what does it do? Frontiers of Hormone Research 42 163-174. (doi:10.1159/000358345)

Evron T, Peterson SM, Urs NM, Bai Y, Rochelle LK, Caron MG \& Barak LS 2014 G Protein and beta-arrestin signaling bias at the ghrelin receptor. Journal of Biological Chemistry 289 33442-33455. (doi:10.1074/jbc.M114.581397)

Fukumori R, Mita T, Sugino T, Hasegawa Y, Kojima M, Kangawa K, Obitsu T \& Taniguchi K 2013 Effects of intravenous ghrelin injection on plasma growth hormone, insulin and glucose concentrations in calves at weaning. Animal Science Journal $\mathbf{8 4}$ 310-315. (doi:10.1111/asj.12001)

Gauna C, van de Zande B, van Kerkwijk A, Themmen AP, van der Lely AJ \& Delhanty PJ 2007 Unacylated ghrelin is not a functional antagonist but a full agonist of the type 1a growth hormone secretagogue receptor (GHS-R). Molecular and Cellular Endocrinology 274 30-34. (doi:10.1152/ajpendo.00414.2009)

Gil FM, de Camargo GM, Pablos de Souza FR, Cardoso DF, Fonseca PD, Zetouni L, Braz CU, Aspilcueta-Borquis RR \& Tonhati H 2013 Polymorphisms in the ghrelin gene and their associations with milk yield and quality in water buffaloes. Journal of Dairy Science 96 3326-3331. (doi:10.3168/jds.2012-6362)

Granata R, Settanni F, Biancone L, Trovato L, Nano R, Bertuzzi F, Destefanis S, Annunziata M, Martinetti M, Catapano F, et al. 2007 Acylated and unacylated ghrelin promote proliferation and inhibit apoptosis of pancreatic beta-cells and human islets: involvement of $3^{\prime}, 5^{\prime}$-cyclic adenosine monophosphate/protein kinase A, extracellular signal-regulated kinase $1 / 2$, and phosphatidyl inositol 3-Kinase/Akt signaling. Endocrinology 148 512-529.

Published by Bioscientifica Ltd. 
Heppner KM, Piechowski CL, Muller A, Ottaway N, Sisley S, Smiley DL, Habegger KM, Pfluger PT, Dimarchi R, Biebermann H, et al. 2014 Both acyl and des-acyl ghrelin regulate adiposity and glucose metabolism via central nervous system ghrelin receptors. Diabetes $\mathbf{6 3}$ 122-131. (doi:10.2337/db13-0414)

Howard AD, Feighner SD, Cully DF, Arena JP, Liberator PA, Rosenblum CI, Hamelin M, Hreniuk DL, Palyha OC \& Hamelin M 1996 A receptor in pituitary and hypothalamus that functions in growth hormone release. Science 273 974-977. (doi:10.1126/ science.273.5277.974)

Itoh F, Komatsu T, Kushibiki S \& Hodate K 2006 Effects of ghrelin injection on plasma concentrations of glucose, pancreatic hormones and cortisol in Holstein dairy cattle. Comparative Biochemistry and Physiology Part A: Molecular \& Integrative Physiology 143 97-102. (doi:10.1016/j.cbpa.2005.11.001)

Jedrzejczak M \& Szatkowska I 2014 Bovine mammary epithelial cell cultures for the study of mammary gland functions. In Vitro Cellular \& Developmental Biology: Animal 50 389-398. (doi:10.1007/s11626013-9711-4)

Kern A, Grande C \& Smith RG 2014 Apo-Ghrelin Receptor (apoGHSR1a) regulates dopamine signaling in the brain. Frontiers in Endocrinology 5 129. (doi:10.3389/fendo.2014.00129)

Kojima M, Hosoda H, Date Y, Nakazato M, Matsuo H \& Kangawa K 1999 Ghrelin is a growth hormone releasing acylated peptide from stomach. Nature $\mathbf{4 0 2}$ 656-660. (doi:10.1038/45230)

Larrea F, Sánchez-González S, Méndez I, García-Becerra R, Cabrera V \& Ulloa-Aguirre A $1999 \mathrm{G}$ protein-coupled receptors as targets for prolactin actions. Archives of Medical Research 30 532-543. (doi:10.1016/S0188-0128(99)00056-1)

Li SN, Wang W, Fu SP, Wang JF, Liu HM, Xie SS, Liu BR, Li Y, Lv QK, Li ZQ, et al. 2013 IL-21 modulates release of proinflammatory cytokines in LPS-stimulated macrophages through distinct signaling pathways. Mediators of Inflammation 2013548073. (doi:10.1155/2013/548073)

Li B, Zeng M, He W, Huang X, Luo L, Zhang H \& Deng DY 2015 Ghrelin protects alveolar macrophages against lipopolysaccharideinduced apoptosis through growth hormone secretagogue receptor 1a-dependent c-Jun N-terminal kinase and Wnt/beta-catenin signaling and suppresses lung inflammation. Endocrinology 156 203-217. (doi:10.1210/en.2014-1539)

Muller TD, Nogueiras R, Andermann ML, Andrews ZB, Anker SD, Argente J, Batterham RL, Benoit SC, Bowers CY, Broglio F, et al. 2015 Ghrelin. Molecular Metabolism 4 437-460. (doi:10.1016/j. molmet.2015.03.005)

Murney R, Stelwagen K, Wheeler TT, Margerison JK \& Singh K 2015 The effects of milking frequency on insulin-like growth factor I signaling within the mammary gland of dairy cows. Journal of Dairy Science $\mathbf{9 8}$ 5422-5428. (doi:10.3168/jds.2015-9425)

Nakahara K, Hayashida T, Nakazato M, Kojima M, Hosoda H, Kangawa K \& Murakami N 2003 Effect of chronic treatments with ghrelin on milk secretion in lactating rats. Biochemical and Biophysical Research Communications 303 751-755. (doi:10.1016/S0006-291X(03)00414-5)

Ogorevc J \& Dovc P 2015 Relative quantification of beta-casein expression in primary goat mammary epithelial cell lines. Genetics and Molecular Research 14 3481-3490. (doi:10.1186/s40104-016-0070-3)
Pinkney J 2014 The role of ghrelin in metabolic regulation. Current Opinion in Clinical Nutrition \& Metabolic Care 17 497-502. (doi:10.1097/MCO.0000000000000101)

Reano S, Graziani A \& Filigheddu N 2014 Acylated and unacylated ghrelin administration to blunt muscle wasting. Current Opinion in Clinical Nutrition \& Metabolic Care 17 236-240. (doi:10.1097/ MCO.0000000000000049)

Roche JR, Sheahan AJ, Chagas LM, Blache D, Berry DP \& Kay JK 2008 Long-term infusions of ghrelin and obestatin in early lactation dairy cows. Journal of Dairy Science 91 4728-4740. (doi:10.3168/ jds.2008-1193)

Savino F, Benetti S, Lupica MM, Petrucci E, Palumeri E \& Cordero di Montezemolo L 2012 Ghrelin and obestatin in infants, lactating mothers and breast milk. Hormone Research in Paediatrics 78 297-303. (doi:10.1159/000345876)

Sorg D, Potzel A, Beck M, Meyer HH, Viturro E \& Kliem H 2012 Effects of cell culture techniques on gene expression and cholesterol efflux in primary bovine mammary epithelial cells derived from milk and tissue. In Vitro Cellular \& Developmental Biology: Animal 48 550-553. (doi:10.1007/s11626-012-9544-6)

ThidarMyint H \& Kuwayama H 2008 Role for des-acyl ghrelin in the responsiveness of plasma hormones and metabolites to ghrelin in Holstein steers. Domestic Animal Endocrinology 35 190-197. (doi:10.1016/j.domaniend.2008.04.002)

ThidarMyint H, Yoshida H, Ito T \& Kuwayama H 2006 Dose-dependent response of plasma ghrelin and growth hormone concentrations to bovine ghrelin in Holstein heifers. Journal of Endocrinology 189 655-664. (doi:10.1677/joe.1.06746)

Xiang Y, Li Q, Li M, Wang W, Cui C \& Zhang J 2011 Ghrelin inhibits AGEs-induced apoptosis in human endothelial cells involving ERK1/2 and PI3K/Akt pathways. Cell Biochemistry and Function 29 149-155. (doi:10.1002/cbf.1736)

Yin Y, Li Y \& Zhang W 2014 The growth hormone secretagogue receptor: its intracellular signaling and regulation. International Journal of Molecular Sciences 15 4837-4855. (doi:10.3390/ ijms15034837)

Yoh J, Nishi Y, Hosoda H, Tajiri Y, Yamada K, Yanase T, Doi R, Yonemoto K, Kangawa K, Kojima M, et al. 2011 Plasma levels of n-decanoyl ghrelin, another acyl- and active-form of ghrelin, in human subjects and the effect of glucose- or meal-ingestion on its dynamics. Regulatory Peptides 167 140-148. (doi:10.1016/j. regpep.2010.12.010)

Yu AP, Pei XM, Sin TK, Yip SP, Yung BY, Chan LW, Wong CS \& Siu PM 2014 Acylated and unacylated ghrelin inhibit doxorubicin-induced apoptosis in skeletal muscle. Acta Physiologica 211 201-213. (doi:10.1111/apha.12263)

Yu AP, Pei XM, Sin TK, Yip SP, Yung BY, Chan LW, Wong CS \& Siu PM 2015 [D-Lys3]-GHRP-6 exhibits pro-autophagic effects on skeletal muscle. Molecular and Cellular Endocrinology 401 155-164. (doi:10.1111/apha.2015.214.issue-2)

Zhang W, Yu G, Huang Y, Xu D, Ren J, Jiang L, Wu C \& Tong D 2013 Expression of ghrelin and GHSR-1a in mammary glands of dairy goat during the lactation and the effects of gherlin on regulation of mammary function in vitro. Molecular and Cellular Endocrinology 370 20-31. (doi:10.1016/j.mce.2013.02.008)

Received in final form 23 January 2016

Accepted 10 February 2016

Accepted Preprint published online 12 February 2016 http://jme.endocrinology-journals.org

DOI: 10.1530/JME-15-0287
() 2016 Society for Endocrinology Printed in Great Britain
Published by Bioscientifica Ltd 